\title{
Kropskultur og religion. Idræt som vare eller leg
}

\section{Betænkninger i anledning af Hans Bondes bog Sport - en moderne kult. Hovedland 1993}

\author{
Af Johannes Adamsen
}

Efter Danmarks fodboldlandskamp d. 25.8. 1993, hvor Michael Laudrup deltog for første gang i flere år, viste DR et lille potræt af ham, hvori indgik flere langsomme gengivelser med ham og en bold og med underlægningsmusik fra Händels Messias. Spøgefuldt? Blasfemisk? Dumt? Eller 'bare' absolut' despekt for musik? I hvert fald kom der efterfølgende et interview med idrætsforskeren Claus Bøje fra Gerlev Idrætshøjskole, hvor han gravalvorligt forklarede det endnu lyttende tv-publikum at fodbold (næsten) er religion.

$\mathrm{Nu}$ er det næppe en fiks idé hos Bøje at drage den sammenligning, og næppe heller er den fremkaldt på fjernsynets forespørgsel. Ideen har af bl.a. idrætsforskere været luftet flere gange i de seneste år, ofte med udgangspunkt i OL eller scenerne i forbindelse med fodboldlandskampene - herrelandsholdets, hvis nogen skulle være $\mathrm{i}$ tvivl. Ja, selv daværende sognepræst og nuværende Århus-bisp, Kjeld Holm, har »ligefrem sidestillet beretningen om Kristi frelsergerning med frasagnet om fodboldbanens helte«, som Knud Bjarne Gjesing, forhåbentligt reelt, gengiver det. ${ }^{1}$ »Jeg får det aldrig løftet ud af mit sind «, siger Kjeld Holm om EM '92.
En af de idrætsforskere som flere gange har været inde på tankegangen har nu skrevet en bog med titlen Sport - en moderne kult, uden spørgsmålstegn efter titlen. I den anledning kan man jo reflektere lidt over religion såvel som over idrætten i dag, ${ }^{2}$ og ikke mindst over deres indbyrdes forhold og fælles betingelser i et moderne samfund. Mit ærinde her er at anholde og belyse den forståelse af idræt med samt selvmodsigelser, som tydeligvis har en betragtelig udbredelse i kredse med interesse i idræt og idrættens placering i samfundslivet.

Bogens forfatter, Hans Bonde, er ansat på Historisk Institut ved Københavns Universitet og har gennem adskillige år beskæftiget sig med idrætshistorie; derudover er han aktiv judoudøver, en disciplin hvori han har ni danmarksmesterskaber. Ydermere har han på det seneste gjort sig til talsmand for »mandeforskning «, en relativ ny disciplin, vistnok uden klare kampregler.

Hans Bonde vil meget med sin bog som alligevel er ganske kort (137 sider). Et stikordsagtigt referat vil lyde, at ud fra en historisk redegørelse for den moderne idræts fødsel omkring århundredeskiftet, hvor det æstetiske og opdragende i den adelige kul- 
tur langsomt må vige for et ideal om effektivitet, hvor det optimale giver plads for det maksimale, er sporten via en alliance med -moderne teknologi blevet en ekstrem, elitær proces, og så meget teknisk styret at præcis det fascinerende menneskelige element er truet, bl.a. af doping, rekorder ved hjælp af forbedrede spyd, løbeunderlag, cykler, dragter, osv. (jf. også hans kronik »Teknosport« i Dagbladet Information 2./3. oktober 1993).

Det er ikke mindst denne fascinerende sport der med det olympiske motto citius, altius, fortius (hurtigere, højere, stærkere) fors $\emptyset$ ges forstået under kultens optik: Sport er det sted »hvor moderne mennesker dyrker deres samfunds kerneværdier« (s. 7).

Denne kultiske idrætsform karakteriseres som mandlig (kønsaspektet kommer jeg ikke ind på, skønt væsentlig nok), og nu er det Bondes opfattelse at denne form har fået konkurrence af en kvindelig, ekspressiv idrætsform med andre betoninger og idealer, bl.a. som i de »eksotiske« idrætsgrene, fx orientalske kampformer som judo, karate og taekwondo. (Sluttelig leger han med den tanke at også disse former kan fortrænges - af virtual reality!).

Inden jeg nu kommer rmed nogle overvejelser til forskellige problemer jeg mener at se, en kort beklagelse: Bogen hævdes $i$ indledningen at sigte på bl.a. uddannelsesinstitutioner. Alligevel får vi næsten ingen referencer, intet indeks og ingen litteraturliste. Heller ikke bøger som Hans Peter Rolfsens Doping. Sporten på sprøjten (Borgen 1991) eller Vyv Simson og Andrew Jennings' Ringenes Herre: Magt, penge og stoffer $i$ De olympiske Lege (Vinten 1992) (om fascisten Samaranch og den selvbestaltede og horribelt magtfulde Internationale Olympiske Komité) er fundet værdige til at nævnes, skønt Hans Bonde temmelig sikkert har lært en del af dem. Hvorfor ikke?
Hans Bondes hovedtese, i fald han kan udkrystallisere en enkelt sådan, er at moderne sport har kultisk karakter eller er kult, fordi et givet samfund i kulten dyrker de $\gg$ fælles værdier i sanselige dramaer«, og sporten har en »stærk symbolkraft« fordi der »udtrykkes grundlæggende idealer med kroppen« (s. 7). I idrætten kan mennesker »opleve ekstase, fællesskab, identitet og tryghed « (s. 9, jf. s. 47 og 132). Selv om Bonde fremhæver disse angiveligt kultiske former er sport ikke nogen religion, fordi »Hvis sport skal blive en religion skal den rumme en skabelsesmyte«, hvorfor sporten kun kan siges at indeholde et religiøst aspekt « (s. 47).

Det mærkelige og slående ved hele Bondes argumentation er at den er så indlysende korrekt, at - formoder jeg - de allerfleste uden videre vil sige: Ja, sådan er det! Ikke desto mindre er synspunktet højst en halv sandhed, hvilket betyder at under en anden synsvinkel er det grundlæggende forfejlet. Det er det fordi forfatterens forudsætninger tvinger ham til simultant at bejae og benægte de samme fænomener. En af disse basale forudsætninger, vel dén basale forudsætning, er, hvad jeg skal vise mere udførligt fra forskellige vinkler, at kroppen og kropsfascinationen og det sanselige kan danne udgangspunkt for et samfund, for religion og altså for sport.

I meget stor udstrækning er Bondes grundopfattelse den at sporten fascinerer og at den følgelig har sin fremragende position fordi mennesker grundlæggende vil fascineres. (NB! fra begyndelsen er perspektivet tilskuernes, ikke udøverens). Idrætsfolk fascinerer ikke alene ved rekorderne, dvs. det de kan, men også »med de kroppe som sætter rekorderne, ved kroppens former« (s. 52). Og vi kan ikke bare slippe rekordjageriet, for »rekorderne er ikke en tilfældig 
skør idé, men legemliggør centrale ideer i vor kultur« (s. 68). Derfor kan sporten miste $\sin$ fascinationskraft hvis rekorderne udebliver (jf. s. 72).

Her er Hans Bonde ikke videre entydig, for moderne mennesker dyrker deres samfunds værdier i sporten (dvs. rekorderne, fremskridtet, den perfekte krop, jf. s. 74), og alligevel er fodbold nationalsporten (herhjemme) fordi der heri udtrykkes en »rigdom af følelser »i » forskellige koder: Den nationale kode; heltene; den seksuelle kode; udløsningen; den religiøse kode; miraklet, den maskuline kode; »drengene«, og krigerkoden; angrebsmaskinen « (s. 85). Nationalsporten fodbold analyseres ikke med udgangspunkt $i$ at den fascinerer men fodbolden - i landholds- og nationalsammenhæng vel at mærke - ses som en communitas-oplevelse à la Victor Turner (s. 87), og Bonde henviser endvidere til Mikhail Bakhtins begreb om karnevalskulturen og det groteske (s. 86). - Nået så langt trækker Bonde i land og ender med at »Eksistensen af sportsaktiviteter $i$ et moderne samfund er med til at give mennesker en ramme af meningsfuldhed, tryghed og fællesskab« (s. 93, jf. s. 132).

Når forfatteren kan få sporten til at udtrykke så forskelligartede ting som samfundets dyrkelse af sin egen fremskridtstro ${ }^{3}$ på den ene side, og på den anden side ønsket om mening, tryghed og fællesskab, vidner det næppe om en systematisk og entydig indfaldsvinkel. Men de forskellige aspekter kan vel alligevel forstås under synsvinklen kroppen, det kropslige og fællesskabet herom. Men spørgsmålet bliver så om det er det kropslige eller det kroppen angives at symbolisere, som dyrkes?

Kritisk som Bonde er mod sportens udvikling og ikke mindst mod den naturvidenskabelige/teknologiske eksperimentering med legemet, foreslår han at satse på den alternative (dvs. den ekspressive; asiatisk kampsport o.1.) idræts fascinationskraft, men dèt er ikke nok, der skal »en ny etisk autoritet til«, »en udvikling af religiøst-etiske instanser, måske $\mathrm{i}$ form af en fornyet kristendom uden had til kødet, ja med kærlighed til kroppen?« (s.136f.) Nok er Bonde fascineret af den kropslige fryd $i$ idrætten som det også fremgår af D.H. Lawrence-citatet s. 11: » Vi burde danse af fryd over, at vi er i live i kødet, og del af det levende, legemliggjorte kosmos«; men i lyset af »tekno-sporten«, som Bonde jo meget rammende benævner moderne sport, $\emptyset$ nsker han en ny etisk forsvarlig kropsdyrkelse. På den ene side, altså, ses sporten som kult og med religiøse aspekter, men er ikke religion grundet den manglende skabelsesmyte, på den anden side satser Bonde på en alternativ sport med fornyet fascinationskraft - men religiøst-etisk kontrolleret.

Mig forekommer det at analysen ikke er ført til bunds, fordi Bonde oscillerer mellem uforenelige interesser (kritik, etik, fællesskab og fascination) og fordi han er bundet til en problematisk præmis: det kropslige som mål og formål.

Fascinationen kommer af samme ord som facisme, og faktisk strejfer Bonde begrebet idet han forsvarer hysteriet $\mathrm{i}$ forbindelse med fodboldeuropamesterskabet i juni 1992 imod beskyldningerne for at være fascistisk. Bonde har bestemt ret $\mathrm{i}$ at det og lignende masseoptrin ikke er fascisme men begrundelsen er godt nok særdeles skrøbelig: »Fascismens stærke symboler, massescenografi og æstetisering af det politiske liv får gennemslagskraft i et udtørret, overintellektualiseret samfund uden dramaer, livgivende ritualer og oplevelser af det kollektive sus. Fodbold-, karnevals-, spejderog rockkulturens eksistens betyder at fa- 
cismen ikke kan melde sig på banen som leverand $\varnothing \mathrm{r}$ af grænseoverskridende oplevelser « (s. 88). Faktisk afslører citatet sna-rere en sammenhæng mellem sport og facisme, idet de implicit hævdes at tilbyde det samme!

Da Toni Schumacher for nogle år siden udgav sin bog Udspark (Systime 1987, tysk 1982) vakte den opsigt for dens afsløringer af den udbredte doping, bestikkelse, fysisk nedbrydning m.m., men det virkelig uhyggelige som man burde have taget fat $\mathrm{i}$ var den rent ud fascistiske holdning: En infam absolutering af fodbold som livets eneste mål i forhold til hvilket alt må vige, og en dertil hørende total ligegyldighed med samfund, politik og økonomi - så længe de forskellige dimensioner ikke stillede hindringer for Schumachers fodboldspil, eller rettere: så længe de befordrede og tjente fodboldspillets maksimale muligheder for er det ikke i sidste instans hvad folk (dvs. mænd) vil?

Her ligger det fundamentale problem: Fascismen får ikke »gennemslagskraft $i$ et udtørret, overintellektualiseret samfund uden dramaer, livgivende ritualer og oplevelser af det kollektive sus « pga. dens »stærke symboler, massescenografi og æstesiering af det politiske liv«, men fordi der ikke længere er et korrektiv som kan skabe og fastholde et menneskeligt fællesskab og sætte grænser for dette fællesskabs udfoldelser og rettigheder. Hvis Bonde har ret $\mathrm{i}$ at $\mathrm{fx}$ »fodboldkulturen « forhindrer fascisme ved, som den, at tilbyde »grænseoverskridende oplevelser«, så bliver spørgsmålet hvordan man forhindrer den ene form, fodboldkulturen, $\mathrm{i}$ at slå over $\mathrm{i}$ den anden, fascismen. Spørgsmålet trænger sig på netop fordi der hævdes en ubevidst og uartikuleret kult i sporten, for det er jo akkurat ved at artikulere og forstå hvad man dyrker at manipulation forebygges og udelukkes. (For at et samfund som sådan falder for fascismen skal naturligvis adskillige andre historiske omstændigheder være til stede, som ikke har været og ikke er bl. a. Danmark).

Igen, tingene skal vendes rigtigt: Et samfund udtørrer ikke fordi der mangler livgivende ritualer, men det har ikke livgivende ritualer fordi det ikke mener at kunne dyrke nogen livgiver. Det er vel kun positivistiske, sækulariserede og fantasiforladte videnskabsmænd (ikke mindst - desværre en god hoben sociologer), som kan tro at et samfund i ramme alvor dyrker sig selv dog måske hvis det bliver fascistisk.

Hele ritualinteressen (som han deler med en anden prominenet idrætsforsker, Ove Korsgaard, jf. note 3) står hos Bonde i fuldt flor i kapitlet om »Orientalsk Kampkunst « (s.114-130; spec. s. 114-25): ${ }^{4}$ Ungdomsoprøret var fantastisk vigtigt i kampen for at nedbryde gamle, stivnede og autoritære ritualer. Hvad det kneb med var at sætte nye $\mathrm{i}$ stedet. Ritualer blev i sig selv lagt for had. Barnet blev skyllet ud med badevandet. Nye ritualer opstod dog sporadisk f.eks. inden for rockkulturen, hvor et tusindtalligt publikum badede sig i lyden fra elektriske guitarer og i ekstase hyldede karismatiske rockidoler« (s. 122). I disse sætninger, en uinspirerende miskmask inspireret (?) af både Victor Turner og Max Weber, ville meget have vundet om Bonde havde skrevet former og ikke ritualer. Bonde er født i 1958 og burde vel ikke uden videre overtage »ungdomsoprørets« egen »mytologi«, for dets succes skyldtes vel nøgternt set først og fremmest at åbne døre blev løbet ind: Der hvor formerne var autoritære var de netop dèt fordi de ikke længere havde autoritet.

I denne sammenhæng er Hans Bondes forestillinger om orientalsk kampsports op- 
dragende muligheder også forfængelige. I bedste fald er disse kampformer opdragende, formende og disciplinerende ikke i kraft af ledernes eventuelle autoritet, og denne kan stadig findes i skolen og andre steder, bla. i meget ungdomsarbejde, inkl. fodbold. Med andre ord; Bonde kan ikke slutte fra kropsdisciplin til egentlig opdragelse; skal det være mere end postulat og/eller $\emptyset$ nskedrøm skal det eksemplificeres.

Efter således at have benægtet kult (og ritualer) som nogen videre oplysende måde at analysere sport på, skylder jeg nogle overvejelser til en alternativ vinkel. Det er interessant at en historiker som Hans Bonde med få undtagelser ikke lader sit historiske perspektiv række længere tilbage end ca. to hundrede år (jf. s. 12 ff.). Det er som om Bonde forsøger at indfange sportens væsen $i$ kult ved at begrænse sig til moderne sport. Selv om Bonde er velorienteret $i$ andre kultures idrætsformer, specielt orientalske, og ved at rekordjageriet er unikt for moderne industrikultur (jf. s. 68) giver det ham ikke rigtig anledning til en historisk dybtgående bestemmelsesfors $\emptyset$ g. Betænk med Goethe:

Wer nicht von dreitausend jahren

Sich weiss Rechenschaft zu geben,

Bleib' im dunkeln unerfahren

Mag von Tag zu Tage leben.

Et tankevækkende bud som glimrer ved sit tankevækkende fravær er Johan Huizingas klassiker Homo Ludens. Om kulturens oprindelse i Leg fra $1938 .{ }^{5}$ Huizinga ser legen som fundamentalt karaktiseret ved at den er frivillig (s. 15 f.) og giver følgende definition:

»den er handling som foregår indenfor visse grænser af tid, rum og betydning; som udspilles i en ganske bestemt, definèrbar orden, i overensstemmelse med en række frivillige antagne regler, og udenfor den materielle nyttes eller nødvendigheds felt. Legens stemning er henrykkelse og begejstring, enten af religiøs eller blot festlig natur. Handlingen følges af en følelse af løftelse og spænding og resulterer i glæde og afspænding« (s. 135).

Hvis idrætten fundamentalt kan ses under synsvinklen leg åbnes en række perspektiver, bl.a. et kritisk perspektiv på moderne, mediebevidst, professionel sport, perspektiver som Huizinga selv behandle$\mathrm{de}^{6}-$ men som unægtelig kan få én til at løbe risikoen for at blive kaldt kulturpessimist eller romantiker eller hvilke fraser kritik af moderne fænomener nu bliver mødt med, særligt i de sidste få år. Man kan måske sige at leg - her idræt - er: Inden for bevidst selvsatte regler at bruge kroppen til (i kroppens selvtranscendens) at vise selvforglemmende ud over kroppen, hvorved mennesker i kraft af regler kan indspilles i en større, fælles orden. ${ }^{7}$ Derfor ødelægges legen hvor den ikke tages alvorligt som selvformål og forsøges spændt for andre uvedkommendes byrder. ${ }^{8}$

Der er kun min hensigt at antyde et alternativ som ikke kommer til orde hos Bonde; enhver kan selv studere Homo Ludens og tænke videre. Dette alternativ, legen, viser hvad sport har været og ideelt fortsat kan være - og momentvis er, sætligt uden for medier og - som en tvivlsom gevinst - ofte uden for klubberne. I det store og hele tror jeg man med fordel kan se nutidig sport som noget andet der lige så vel er snævert sammenhørende med en udpræget industrikultur: en vare. Moderne sport er en vare og kroppen er et produkt. Som rekordjag og industrisamfund hører sammen, således kropsopfattelsen og selvsamme industrisamfund (jf. Allen Guttmann, referat hos Bonde, s. 68). 
Moderne sport er nogenlunde jævngammel med moderne industri og de har præmisser fælles, præmisser som også ligger under -nationalismen og forklarer hvorfor sport og nationalisme hænger så enestående godt sammen. (Pudsigt nok dyrkes nationalisme intetsteds så åbentlyst og uimodsagt som til de »olympiske« lege, som hævder alle menneskers grundlæggende fællesskab på tværs af grænser).

\section{I sin Forsømmelsernes Bog (Samleren} 1993) bruger Carsten Jensen udtrykket »infantilisme« og moderne kultur. Desværre er begrebet hverken særlig præcist eller videre oplysende hos forfatteren, og at se vores kultur som essentielt barnlig er ikke engang nyt. Fx bruger Ole Jensen det gennem hele sin bog I vakstens vold (Fremad 1976). Men Huizinga brugte i trediverne det langt bedre udarbejdede begreb "puerilisme« (ibid. s. 207 ff.), og Milan Kundera er begrebsmæssigt inde på en lignende med sit »Homo sentimentalis« (i Udødeligheden; jf. også hans »infantokrati og med forbehold »litost « (i Om latter og glemsel)).

Puerilisme er langt bedre end infantilisme, for det angår nemlig ikke barnets men yndlingens verden (jf. latin infans/infas og puer). Puerilisme er det umodne, uhumoristiske, følelsesanspændte og uforløste, kort sagt en forlænget pubertet. At se også idræt under den synsvinkel giver plads til ungdommens altopslugende begejstring og ensidighed, som der skal være plads til, og giver samtidig blik for det dybt problematiske $i$ angiveligt voksne menneskers dyrkelse af ungdommen. Herved berøves sportsentusiasmen et samfundskorrektiv og lades grundlæggende i stikken, fordi den perspektiverings- og modningsproces, som man skal fortsætte ind i voksenlivet med, er prisgivet, hvorved den sportslige udfoldelse fastfryses som tilfældigt, absolut mål, der udtalt og oftest ubevidst skal give dèn mening som nu ikke menes at være andetsteds. ${ }^{9}$ Legen kan være selvformål fordi livet har mening som et led i et større symbolsk univers, religionen; moderne sport kan derimod absoluteres og få fascistisk tilsnit (jf. Toni Schumacher) fordi den sportsudøvende ikke længere forstår sig som et ansvarligt led af en større helhed. De vanvittige summer, den udbredte kriminalitet, det idiotiske rekordhysteri og den dybt tragiske destruktion af børn og unge mennesker via overtrækning, sprøjter, piller, steroider og andre hormoner osv., lader sig næppe forklare fyldestgørende anderledes: Professionel sport er, nu som i antikken, ${ }^{10}$ al ægte idræts død. ${ }^{11}$

Nu er jeg selvfølgelig klar over at definitionen af religion er - mildt sagt - omstridt, og mange vil nok mene at mit brug af begrebet religion er normativt - det får dog være. Her er det værd at hæfte sig ved at vi naturligvis er nødt til at gøre os klart kvad vi mener med glosen, i særdeleshed hvis det skal være analytisk brugbart. Selv den engelske religionshistoriker Ninian Smarts fremragende syvledede såkaldt operationelle definition $^{12}$ godtager ikke hvad som helst. Nationalisme, humanisme og marxisme kan analyseres ved definitionen, men de er ikke religioner, ikke engang »Quasi-religiøse« bevægelser, de er »secular worldviews«.

Hans Bonde vil netop fastholde at sport ikke er religion. Alligevel er han så meget barn af sin tid at han vil gå fra sport til religion (religionen skal vejlede sporten etisk og selv lære at »elske k $\varnothing$ det $«)^{13}$ hvor det skal være bedre at lade religionen perspektivere sporten, om ikke andet så dog historisk og analytisk. Derfor bliver Bondes bog på en gang spændende, oplysende og indsigtsgivende og tillige analytisk amorf. 
Derfor kan han have et skarpt blik for mange af den moderne sports skyggesider og alligevel ikke gøre andet end at håbe på en alternativ sport som er etisk (religiøst) afsikret. Men at bede om en religion for at få sportslig etik forekommer temmelig enøjet, især taget $\mathrm{i}$ betragtning hvor mange andre steder anstændig og an- og forsvarlig handling er påtrængende. Deler Hans Bonde i sidste instans den snævre fokusering på sporten som menings- og næsten livgiver, som andre ser i kunsten, andre igen i naturen, seksualiteten osv.? Er idrætshistorikeren Hans Bonde ubevidst mere fagspecialiseret end godt er og vil derfor finde, forstå og helbrede et helt samfunds vildskud og foruroligende adfærd isoleret fra samfundet som helhed?

Dog, med udgangspunkt i kroppen og sporten som basalt godt i sig selv (hvad de også kan være), men uden andet end ønsket om en korrigerende instans, forbliver såvel sport som kult og religion underligt konturløse. Og sportens placering i et mindre totalitært perspektiv, dvs. i en sammenhæng hvor religionen giver livet rammer og mening, kan antydes med netop OL: I antikken var der hellige våbenhvile $\mathrm{i}$ to-tre måneder under legene; I vort århundrede aflyses OL pga. krig - krigen er lige så totalitær i vort århundrede som sporten, dog lykkeligvis med andre konsekvenser.

Mine betænkninger skal selvfølgelig ses som et diskussionsindlæg. Fors $\varnothing$ get på at inddrage religionen og kulten som forståelseshjælp er - uanset hvor bagvendt og utilstrækkeligt jeg mener det er gennemført prisværdigt.

Stikordet kropskult(ur) kunne afslutningsvis give anledning til at spørge om kroppen nogensinde har været genstand for kult qua krop, og om i hvilken forstand den faktisk er det i vesten nu om dage.
Legemet har i virkeligheden altid symbolsk fremstillet et større forudgivet hele, som selv endvidere har været artikuleret i myter, fortællinger, dogmer osv., ja, legemet har ofte været symbolet par exellence. ${ }^{14}$ Det tvetydige, hvor kroppen dels hævdes at være selvformål, dels skal være udgangspunkt for en slags mening, er ret ny og tenderer hele tiden mod at sætte intellektet og den kritiske distance ud af spillet: Det er jo »livsfjendtligt« som det ofte har lydt siden Nietzsche.

Filosofihistorisk er denne omvending af prioritetsforholdet mellem sjæl og legeme oplysende, bla. fordi der meget hurtigt kommer mange bud på kropsforståelsen: Fra Feuerbachs »Der Mensch ist, was er isst « til den sene Schellings fremhævelse af viljen frem for tænkningen, Nietzsches destruktion af »die Hinterwelt« og den tilsvarende accentuering af vilje og instinkt, Marx' ekspressive arbejdsbegreb osv. ${ }^{15}$

Når store tænkere som de nævnte kan give første prioritet til så vidt forskellige konceptioner som anført så vidner det om at nok kan sjælens førsterang give anledning til strid også om legemet og den materielle verden, men at gøre op med sjælens guddommelige oprindelse og værdi - uanset den præcisere forståelse heraf - er ikke nogen løsning på en gammel strid, men er $\mathrm{i}$ sig selv et nyt problem hvis baggrund man $i$ vort århundrede har haft så svært ved overhovedet at forstå. Som i mange andre sammenhænge er det også for historikeren og samfundsforskeren essentielt at gøre sig disse forhold klare, hvis ikke hele ansatsen skal undermineres fra begyndelsen.

Hvis altså kropskult er religion er det i sandhed en historisk innovation, men den er akkurat ikke religion og som sporten heller ikke engang egentlig kult, ikke fordi der mangler en skabelsesmyte (det er set før), men fordi mennesker i den religiøse kult al- 
tid har anråbt og dyrket netop de liv- og helsegivende kræfter de ikke selv er eller overhovedet kan være herre over. Der er -med andre ord tale om en ydmyg og taknemmelig realisme, hvis forsvinding i afgørende forstand er betingelsen for moderne kropskultur, herunder sporten. At mennesker er dødeligt og menneskelivet har grænser, dèt er den visdom religion kan artikulere; i det omfang kroppen i moderne sport kan siges at »symbolisere« noget, fx. fremskridtet, er det diffust, ugennemsigtigt eller endog fortrængt, ikke på grund af at det er dybt irrationelt - det er religion i en vis forstand også - men fordi det er menneskefjendsk, inhumant. Sagt på en anden måde: Der er ikke artikuleret og bevidstgjort noget symbolsk univers som kroppen deltager i og symboliserer. Kroppen som religiøst udgangspunkt er ikke muligt fordi kroppen ikke er selvskabt, og når kroppen paradoksalt nok alligevel dyrkes sker det ved reelt at fortrænge og samtidig leve af det fortrængte, meningsgivende centralperspektiv.

Disse sidste betragtninger skal ikke viderføres her. Meningen er at trække argumentationslinjen tydeligt op: Skal man meningsfuldt sige noget om sammenhængen mellem sport og religion, kan det ikke nytte noget at inddrage mere eller mindre tilfældige aspekter af religion, alt afhængig af diverse teorier (hvis holdbarhed og indbyrdes forhold end ikke er overvejet), men man må udarbejde sammenhængen i et historisk dybdeperspektiv, så centrum, tab, udglidninger og nye konstellationer gestaltes klart. Ellers risikerer man netop at spille sig den kritiske distance af hænde som historien så fortrinligt kan levere, ret forstået. En sådan indfaldsvinkel burde vel når alt kommer til alt heller ikke være historikeren Hans Bonde ubekendt.

\section{Noter}

1. I Århus Stiftstidende d. 23.1.94 i anmeldelse af Kjeld Holm, Lidenskab og narvar (Aros 1993). Men, formoder jeg, Kjeld Holm holder vel næppe sport for hverken religion eller næsten religion.

2. Idræt og sport bruger jeg synonymt, selv om de i mange sammenhænge med fordel kan differentieres.

3. Ideen om samfundets dyrkelse af sig selv og/i sine idealer har Bonde (måske via Ove Korsgaard kronik i Information 22./23.8.92, »Fra ritual til ritual«) sandsynligvis fra Emile Durkheims religionsteori - ofte præsenteret urimeligt forkortet. Teorien holder ikke! For en god kritisk oversigt, se Raymond Aron, Les ètapes de la pensèe sociolo- gique (Gallimard 1991 (1967)), s. 317-405; eller kortere: J. van Baal og W.E.A. van Beek, Symbols for commiunication (Van Gorcum, Assen 1985), s. 102-119.

4. Noget ændret i forhold til en artikel i Benny Lihme, red., Forbandede ungdom; også lettere ændret som kronik i Information 20.7.92.

5. Dansk i Gyldendals uglebøger 1963; genoptrykt 1992.

6. Se også Hans Lyngby Jepsen, Idrattens forraderi. en bog om konkurrencesport (Gyldendal 1973).

7. Legen er måske en så elementær vigtig erfaring at hvis den udebliver, ja så spiller man sig en uvurderlig indfaldsvinkel til en dybtgående og sand 
livsforståelse af hænde. Således må man tolke verset af Rainer Maria Rilke og begrunde at den tyske filosof Hans-Georg Gadamer (f. 1900) satte det som en slags hyperkoncentrat af hermeneutikken som mere end tolkningsmetode, nemlig som filosofisk hermeneutik:

Solang du selbstgeworfenes fängst

Geschicklichkeit und lässlicher Gewinn - ; erst wenn du plötzlich Fänger wirst des Balles, den eine ewige Mitspielerin

dir zuwarf, deiner Mitte, in genau

gekonntem Schwung, in einem jener Bögen aus Gottes grossen Brückenbau:

erst dann ist Fangen-können ein Vermögen, Nicht deines, einer Welt.

8. Professionalisme eroderer helt elementært det centrale i leg hvis leg er det formålsløse, energiudladning uden hensigt, for i det professionelle får sporten jo netop hensigt, hvorfor selve tanken bag leg ødelægges, apriori. Jf. Northrop Frye, The Great Code. The Bible and literature (Harvest/ HBJ 1983), s. 125, hvor leg søges tolket som et udtryk for »Skabelsens overskud « - smlg. at Visdommen i Ordsprogenes bog 8.31 »leged på hans vide jord $\ll$.

9. Moderne kunst har selvfølgelig i vid udstrækning samme problem, se Matei Calinescu, Five Faces of Modernity (Duke U.P., Durham 1987).

10. Jf. hertil E. Norman Gardiner, Athletics of the Ancient World (Clarendon Press, Oxford 1955 (1930)), s. 99-116.

11. Eksempler blandt mange, Finn Skårderud, Sulte- kunstnerne. Kultur, krop og kontrol (Tiderne Skifter 1992 (Oslo 1991)), s. 115-23 (om spiseforstyrrelser og sport); »Schweig oder stirb « i Der Spiegel, 4/1994, s. 146-50 (kriminalitet og livsfarligt hormonsalg, frygt for mafiatilstande i salg af muskelopbyggende harmonpræperater). - Ville denne kriminalitet tiltrækkes uden de enorme summer som findes i professionel sport?

12. Ninian Smart, The World's Religions (PrenticeHall, N.J. 1989), s. $10 \mathrm{ff}$.

13. Hans Bondes Forestillinger om kristendommen er beklageligvis urimelig fordumsfulde, præget som de er af vækkelsesbevægelserne, især ved Indre Mission. Mange kristne har i nutiden kunnet tippe over i noget nær krops- (og skabelses-) dyrkelse. I denne kropsdyrkelse gemmer sig en delvis ufordøjet arv fra forrige århundredes religionskritik, en arv der har vænnet folk til en problematisk og uholdbar forestillinger om »den verden « og »en anden verden «. - Denne dualisme trænger til at blive gennemtænkt på ny, også hvad angår forholdet mellem sjæl og legeme.

14. Se fx art. »Human Body« i Encyclopedia af Religion, red. M. Eliade, bd. 6, s. 499-511. jf. også Wilhelm Duprè i sin noget oversete Religion in Primitive Cultures (Mouton, the Hague, Paris 1975) s. 125 og 262, hvor mennesket kaldes »the most synbolic symbol«.

15. Jf. oversigten hos Walter Schulz, Philosophie in der veränderten Welt (Neske, Pfullingen 1972) s. 335-467. 
